\title{
Vegetation Leachate During Arctic Thaw Enhances Soil Microbial Phosphorus
}

\author{
Kate M. Buckeridge, ${ }^{1,2 *}$ Sean M. Schaeffer, ${ }^{1,3}$ and Joshua P. Schimel ${ }^{1}$
}

\begin{abstract}
${ }^{1}$ Ecology, Evolution and Marine Biology, University of California, Santa Barbara, California 93106, USA; ${ }^{2}$ Lancaster Environment Centre, Lancaster University, Lancaster LA1 4YQ, UK; ${ }^{3}$ Biosystems Engineering and Soil Science, University of Tennessee, Knoxville, Tennessee 37996, USA
\end{abstract}

\begin{abstract}
Leachate from litter and vegetation penetrates permafrost surface soils during thaw before being exported to aquatic systems. We know this leachate is critical to ecosystem function downstream and hypothesized that thaw leachate inputs would also drive terrestrial microbial activity and nutrient uptake. However, we recognized two potential endpoint scenarios: vegetation leachate is an important source of $\mathrm{C}$ for microbes in thawing soil; or vegetation leachate is irrelevant next to the large background $\mathrm{C}, \mathrm{N}$, and $\mathrm{P}$ pools in thaw soil solution. We assessed these potential outcomes by making vegetation leachate from frozen vegetation and litter in four Arctic ecosystems that have a variety of litter quality and soil C, N, and P contents; one of these ecosystems included a disturbance recovery chronosequence that allowed us to test our second hypothesis that thaw leachate response would be enhanced in disturbed ecosystems. We added water or vegetation leachate to intact, frozen, winter soil cores and incubated the cores through thaw. We measured soil respiration throughout, and soil
\end{abstract}

Received 3 May 2015; accepted 2 October 2015;

published online 29 December 2015

Author contributions KMB conceived of and designed the study, performed research, analyzed the data, and wrote the paper; SMS conceived of and designed the study, performed research, analyzed the data, and wrote the paper; and JPS conceived of and designed the study, and wrote the paper.

*Corresponding author; e-mail: kmbuckeridge@gmail.com solution and microbial biomass $\mathrm{C}, \mathrm{N}$, and $\mathrm{P}$ pools and gross $\mathrm{N}$ mineralization immediately after a thaw incubation $\left(-10\right.$ to $\left.2^{\circ} \mathrm{C}\right)$ lasting 6 days. Vegetation leachate varied strongly by ecosystem in $\mathrm{C}, \mathrm{N}$, and P quantity and stoichiometry. Regardless, all vegetated ecosystems responded to leachate additions at thaw with an increase in the microbial biomass phosphate flush and an increase in soil solution carbon and nitrogen, implying a selective microbial uptake of phosphate from plant and litter leachate at thaw. This response to leachate additions was absent in recently disturbed, exposed mineral soil but otherwise did not differ between disturbed and undisturbed ecosystems. The selective uptake of $\mathrm{P}$ by microbes implies either thaw microbial P limitation or thaw microbial P uptake opportunism, and that spring thaw is an important time for $\mathrm{P}$ retention in several Arctic ecosystems.

Key words: phosphorus; nitrogen; carbon; tundra; thaw; vegetation leachate; thermokarst; microbial biomass.

\section{INTRODUCTION}

During spring thaw in the Arctic, litter and vegetation is leached by the melting snowpack (Wickland and others 2012). It is usually assumed that because soils are still frozen that most of this leachate is flushed laterally into streams and lakes, where the leachate provides an important nutrient 
subsidy (Michaelson and others 1998; Amon and others 2012). However, although mineral soil remains frozen during this early spring snowmelt, the soil surface organic layer thaws enough to allow the leachate to percolate (Hinzman and others 1991); the nutrients may be taken up and metabolized by microorganisms in this zone (Qualls and others 2002; Cleveland and others 2004). These leachate inputs occur at a time associated with wide swings in microbial biomass and activity — such as a burst of soil organic matter mineralization, a crash in microbial biomass, and accelerated community turnover (Schimel and Clein 1996; Edwards and others 2006; Buckeridge and others 2013). It is unclear how important the flush of plant and litter leachates are to fueling microbial processes during the rapid and intense spring thaw in Arctic ecosystems.

There are two alternate hypotheses for how leachate may affect microbial processes in the surface soil at thaw. The first is that the dissolved organic $\mathrm{C}$ in leachate provides a pulse of high-quality resources that fuels activity of resource-limited microbes, as it does in incubations of boreal vegetation leachate without soil (Wickland and others 2007), when leachate is added to summer alpine soils (Cleveland and others 2004), or during the spring freshet in Arctic aquatic ecosystems (Crump and others 2003; Judd and others 2006; Balcarczyk and others 2009) where terrestrial plant C dominates snowmelt inputs (Amon and others 2012). This hypothesis is consistent with tundra ecosystems being strongly nutrient-limited (Shaver and Chapin 1980; Sistla and others 2012); additions of $\mathrm{C}, \mathrm{N}$, and $\mathrm{P}$ alter aboveground community composition (Hobbie and others 2005), belowground community composition (Clemmensen and others 2006; Deslippe and others 2011), and ecosystem C, $\mathrm{N}$, and P storage (Jonasson and others 1996; Mack and others 2004). Alternatively, leachate may represent a small enough proportion of the total amount of labile material mobilized at soil thaw that it may be effectively irrelevant as a fuel for soil microbes enduring the environmental stress of thaw. Northern vegetation leachate DOC appears to range in biodegradability, with deciduous shrub leaves and mosses having a greater proportion of readily mineralizable DOC than the more common evergreen leaves and stems and deciduous shrub stems (Wickland and others 2007). In addition, thaw leachate additions occur when soils are frozen, albeit at temperatures that allow reduced microbial activity $\left(-2\right.$ to $0^{\circ} \mathrm{C}$; McMahon and others 2009), and already replete with autochthonous soil solution thaw nutrients (Judd and Kling 2002;
Buckeridge and Grogan 2010). These alternate hypotheses represent, of course, end points of a spectrum of effects rather than being discrete alternatives. Distinguishing which pattern holds true, or rather where along the spectrum of possibilities, is important to understand the factors that drive the abrupt pulse of microbial activity that occurs at thaw.

The quality of leachates as microbial substrates is controlled by the chemical composition of the vegetation (Cleveland and others 2004; Wickland and others 2007). Arctic landscapes contain a juxtaposition of different ecosystem types, each with its own patterns of vegetation productivity, nutrient content (Giblin and others 1991; Shaver and Chapin 1991), and DOC quality and concentration (Armstrong and others 2012). As the spring thaw is a critical time for nutrient release in arctic ecosystems, the interaction of fresh plant leachates with the extant soil microbial community provides a possible driver that could either stimulate mineralization of remaining native organic matter (priming), or could serve as a substrate for growth and so immobilize nutrients that might otherwise be lost.

Arctic ecosystems also vary in their disturbance history. A common disturbance in the Arctic results from permafrost thaw; on slopes, melting at the top of the permafrost layer can allow the thawed soil to detach and slump downslope, exposing fresh material which can then continue to thaw-these thermo-erosional features are known as retrogressive thaw slumps, or more commonly, thermokarsts-and are common in northern Alaska (Bowden and others 2008; Gooseff and others 2009) and western Canada (Lantz and Kokelj 2008). Landscape succession after thermokarst is characterized by rapid initial ( $\sim 50$ years) plant growth on the denuded mineral soil, which only accumulates a new organic horizon slowly (Pizano and others 2014). The rapid regrowth early in recovery requires a large supply of nutrients. Arctic ecosystems are strongly dependent on the recycling of nutrients from organic matter (Chapin and Bloom 1976), so it is unclear where those nutrients come from in this bare soil, and what processes regulate nutrient mineralization through the recovery of these thermokarst systems (Vitousek and Reiners 1975; Rastetter and others 2013). Spring thaw vegetation leachates are a potential source of nutrients, and this allochthonous (upslope) source may be particularly important in early, low organic matter stages of ecosystem recovery.

We evaluated the effects of fresh plant leachates on soil microbial processes in Alaskan tundra systems that were undisturbed or in various stages of 
the thaw-slump/recovery cycle during the critical spring thaw period; we tested the following hypotheses: (1) leachates are important stimulants to soil microbial activity and nutrient immobilization at thaw; and (2) the leachate response is enhanced in disturbed ecosystems and diminishes as ecosystems recover and organic matter accumulates. We collected soils from a variety of arctic ecosystem types and in one, from several stages of thermokarst disturbance/recovery; we incubated them through thaw with and without added vegetation leachate. We measured respiration through the incubation and soil and microbial nutrient pools and gross $\mathrm{N}$ mineralization at the end of the thaw incubation.

\section{MethoDs}

\section{Site Description}

This study was conducted at sites representing four ecosystem types (Table 1) within $8.5 \mathrm{~km}$ of the Arctic long-term ecological research (LTER) site at Toolik Lake, Alaska $(68.38 \mathrm{~N}, 149.43 \mathrm{~W})$. The landscape is the gently rolling foothills of the Brooks Range, underlain by continuous permafrost. Annual average temperature is $-7^{\circ} \mathrm{C}$; temperatures are generally above freezing between June and August, with an average air temperature of $10^{\circ} \mathrm{C}$ in July, but temperatures are regularly below $-30^{\circ} \mathrm{C}$ in winter (Shaver and others 2006). Soil temperatures in the summer vary from $10^{\circ} \mathrm{C}$ at the surface to $0^{\circ} \mathrm{C}$ at the top of the active layer, while in winter, they average -5 to $-8^{\circ} \mathrm{C}$ at $10-\mathrm{cm}$ depth (Shaver and others 2006). Annual precipitation is $318 \mathrm{~mm}$ with $43 \%$ falling as snow, and thaw (snowmelt) typically occurs in late May to early June (http://ecosystems.mbl.edu/ARC/).

Three of our sampled ecosystem types represent dominant tundra communities in moist acidic 'tussock' and 'heath' tundra, and moist non-acidic 'tall shrub' tundra, previously described in detail (Shaver and Chapin 1991; Gough and others 2002). Tussock tundra is a moderately productive system, dominated by a sedge (Eriophorum vaginatum) that forms dense tussocks of annual rhizomes that accrete over decades, interspersed with inter-tussock depressions that are poorly drained. Within inter-tussock spaces, deciduous and evergreen shrubs and mosses are present. Heath tundra is often found on exposed ridges that have shallow snow cover in winter; soils are coarse textured, rocky, and typically thaw deeply in summer. Heath tundra has a thin organic horizon and is dominated by patchy, evergreen, cryptogram vegetation. Tall shrub tundra is characterized by a shallow, loose organic horizon over gravelly soils, dominated by a tall $(0.5-1 \mathrm{~m})$ over story of deciduous shrubs (Betula nana and Salix glauca), and a thin understory of mosses and some forbs.

The fourth ecosystem is a thermokarst chronosequence of four retrogressive thaw slumps (RTS) at Lake NE-14 (68.68N, 149.62W). We compared these disturbed stages to the undisturbed ecosystem around the RTS chronosequence, which is low shrub moist non-acidic tundra ('undisturbed

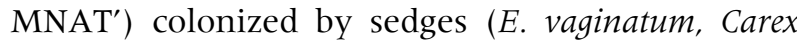
spp.), low shrubs (B. nana, Salix spp.), evergreen shrubs (Ledum palustre, Vaccinium vitis-idaea), and feather mosses. The chronosequence includes the 4 scars on the north to north-west shore characterized as age since disturbance (by ${ }^{14} \mathrm{C}$ dating of the moss and shrub-ring aging, Pizano and others 2014 ) as 5, 42, 46, and approximately 150 years, in close proximity, and ranging in size from 0.6 to 2.3 ha. The 5 -year-old scar was dominated by exposed mineral soil that was bare or was covered in sparse patches of thin moss, S. glauca seedlings or mats of Equisetum ('recent mineral'). However, this recent scar also contained upright tundra peds

Table 1. Ecosystem/Chronosequence Characteristics

\begin{tabular}{|c|c|c|c|c|c|c|c|c|c|}
\hline Tundra type & Age/ecosystem & Soil & $\mathrm{pH}$ & $\begin{array}{l}\mathrm{BD} \\
\left(\mathrm{g} \mathrm{cm}^{-3}\right)\end{array}$ & $\begin{array}{l}\text { Moisture } \\
(\%)\end{array}$ & $\begin{array}{l}\text { Depth } \\
(\mathrm{cm})\end{array}$ & $\begin{array}{l}\text { Total C } \\
(\%)\end{array}$ & $\begin{array}{l}\text { Total N } \\
(\%)\end{array}$ & $\mathrm{C} / \mathrm{N}$ ratio \\
\hline \multirow[t]{5}{*}{ Thermokarst } & Recent mineral & M & 9.1 & 0.83 & 5 & $5.0^{1}$ & 1.8 & 0.06 & 37.5 \\
\hline & Recent rafts & $\mathrm{O}$ & 6.7 & 0.25 & 66 & 7.0 & 24.1 & 1.36 & 22.1 \\
\hline & Intermediate & $\mathrm{O}$ & 6.8 & 0.14 & 306 & 5.5 & 31.5 & 1.26 & 30.1 \\
\hline & Old & $\mathrm{O}$ & 5.6 & 0.09 & 292 & 6.1 & 36.0 & 1.76 & 23.9 \\
\hline & Undisturbed MNAT & $\mathrm{O}$ & 5.3 & 0.10 & 316 & 6.9 & 39.2 & 1.52 & 31.0 \\
\hline \multirow[t]{3}{*}{ Non-thermokarst } & Heath & $\mathrm{O}+\mathrm{M}$ & 5.2 & 0.58 & 42 & 4.8 & 11.2 & 0.53 & 23.4 \\
\hline & Tall Shrub & $\mathrm{O}$ & 6.1 & 0.07 & 452 & 6.4 & 38.5 & 1.47 & 25.5 \\
\hline & Tussock & $\mathrm{O}$ & 4.9 & 0.09 & 339 & 7.5 & 36.3 & 0.51 & 70.5 \\
\hline
\end{tabular}


$\left(\sim 0.2 \mathrm{~m}^{2}\right)$ of vegetation that had separated from the collapsing headwall, initially rafting on the mineral slurry then becoming entrained in the solidified mineral soil. The vegetation on the upright rafts was similar to the undisturbed tundra above, with some additional colonization by grasses. We hypothesized that these organic tundra rafts ('recent rafts') may act as nutrient sources for the surrounding scar, especially at thaw.

The approximately 42- and 46-year-old scars ('intermediate') had a developing layer of organic soil, a larger range of microtopography and soil heterogeneity than undisturbed tundra, and were dominated by shrubs (B. nana and Salix spp.). These shrubs were denser and taller (up to $2 \mathrm{~m}$ ) than those found on the surrounding undisturbed tundra. The vegetation and topography of the approximately 150-year-old scar ('old') was almost indistinguishable from the surrounding tundra and was detected only through remote sensing (Google Earth) by the shadow of the headwall and scar edge.

\section{Soil and Litter Collection and Leachate Production}

Retrogressive thaw slumps are characterized by a headwall at the top of the slope, which continues to erode for several years after the initial slump, and by a zone of deposition at the foot of the slump; this lower zone is disturbed frequently by temporary water tracks. In each thaw slump in the chronosequence, we established a transect across the most stable part of the slump that lies at the transition between the retrogressing head zone and the depositional foot zone. In March 2011, intact soil blocks $\left(\sim 12 \mathrm{~cm}^{2} \times 6 \mathrm{~cm}\right.$ deep, varying by organic matter depth; 5 -cm deep for mineral soils) were collected from the frozen ground beneath the snow pack, using an axe and hammer. We collected five blocks each from tussock tundra, the heath tundra, the tall shrub, the four thermokarst scar transects (plus the floating tundra rafts in the recent scar), and from the undisturbed tundra above the scars (approximately $20 \mathrm{~m}$ away from the edge of the slump to avoid the effects of the slump on soil processes). All soils were organic with the exception of the mineral soil in the recent scar (that is the newly exposed mineral soil), and the heath tundra, which was primarily mineral soil with a thin $(0.3-1 \mathrm{~cm})$ organic horizon.

To make litter leachate, we collected plants and litter from the ecosystems from which soil was collected: tussock tundra, heath tundra, tall shrub tundra, and above the thermokarst scars on the undisturbed tundra. One block $\left(\sim 0.5 \mathrm{~m}^{2}\right)$ of vegetation from the tussock, heath, and tall shrub and three blocks of vegetation from the thermokarst were clipped to the organic soil surface after gently clearing the snow blanket. We therefore collected frozen live plants, litter from the previous year and partially decomposed litter from previous years. All vegetation was bagged and returned to the field laboratory and kept frozen until leachate preparation. To make the leachate, we soaked the frozen vegetation in cold distilled water (300-400 g frozen vegetation/L) in large tubs in a $4^{\circ} \mathrm{C}$ fridge; the leachates fluctuated between -0.2 and $+0.5^{\circ} \mathrm{C}$ for 4 days. We then poured the leachates through cheesecloth to remove plant material. The leachates were frozen and returned to the laboratory at the University of California Santa Barbara where they were successively filtered down to $1.0-\mu \mathrm{m}$ pore size.

\section{Soil Handling, Incubation, and Extraction}

Soils were kept frozen throughout the subsampling process and subsampled with a large cleaver to maintain soil structure. Each frozen soil block had the live vegetation (including moss) removed with scissors and then was subsampled for bulk density and soil moisture calculations and to create six intact incubation cores: (1) two cores for measuring soil respiration through thaw, followed by C, N, and P pools at the end of thaw; and (2) two initials and (3) two final cores for measuring gross $\mathrm{N}$ mineralization at thaw. The duplicate cores were for leachate and water (control) additions.

Respiration cores $(\sim 43 \mathrm{~g} \mathrm{fw})$ were each placed in a 125-ml glass food-canning (Mason) jar, which had a septum in the lid for gas sampling. Gross mineralization cores $(\sim 10 \mathrm{~g} \mathrm{fw})$ were placed in a 50-ml centrifuge tube. We added leachate at a constant volume (instead of a constant mass), so as to not delay the start of the incubation with leachate analysis and associated constant-mass processing. Either water or the appropriate ecosystemsource-leachate was then added to each core: 10 (all organic soils), 2 (Bare mineral), or 4 (Heath) $\mathrm{ml} \mathrm{g}^{-1} \mathrm{dw}$ soil. Cores were then were placed in a rack in a 'cryocooler' at $-10^{\circ} \mathrm{C}$ for 4 days; this initial period acclimatized the soil to the initial disturbance. The cryocooler was created by circulating propylene glycol in a commercial chest freezer $\left(-20^{\circ} \mathrm{C}\right)$ with a heating pump that increased the temperature as required; temperature was controlled with the pump thermostat and confirmed with a thermometer. All cores were then 
incubated through thaw, from -10 to $+2{ }^{\circ} \mathrm{C}$ over 6 days with stepped increases by $2^{\circ} \mathrm{C}$ every day. Respiration was measured daily in each Mason jar (plus three leachate and water controls without soil) as $\mathrm{CO}_{2}$ concentration in $1 \mathrm{ml}$ of headspace, on a LI-820 $\mathrm{CO}_{2}$ analyzer (LICOR, Lincoln, Nebraska, USA). At the end of the incubation, respiration cores were broken down by mixing soil and water/ leachate to form a slurry and then subsampled into several vessels for extraction with $0.5 \mathrm{M} \mathrm{K}_{2} \mathrm{SO}_{4}$ (for measuring extractable $\mathrm{NH}_{4}{ }^{+}-\mathrm{N}, \mathrm{NO}_{3}{ }^{-}-\mathrm{N}$, organic $\mathrm{C}$, and organic N), with $0.5 \mathrm{M} \mathrm{K}_{2} \mathrm{SO}_{4}+1 \mathrm{ml} \mathrm{CHCl}_{3}$ (for the microbial biomass $\mathrm{C}$ and $\mathrm{N}$ flush) (Fierer and Schimel 2003), with $0.5 \mathrm{M} \mathrm{NaHCO}$ (for extractable $\mathrm{PO}_{4}-\mathrm{P}$ ), and with $0.5 \mathrm{M} \mathrm{NaHCO} \mathrm{N}_{3}+$ $1 \mathrm{ml} \mathrm{CHCl}{ }_{3}$ (for the microbial biomass $\mathrm{P}$ flush). We did not measure organic $P$ in the microbial biomass and assumed that this was an insignificant part of the extractable microbial $\mathrm{P}$, as in other studies (Brookes and others 1982; Jonasson and others 1996; Buckeridge and Grogan 2010).

Also at the end of the incubation, gross mineralization cores were injected with 0.3 (all organic soils) or 0.04 (Bare mineral and Heath) $\mu \mathrm{g} \mathrm{N} \mathrm{g}^{-1}$ $\mathrm{dw}$ soil of $99 \% 0.1 \mathrm{mM}{ }^{15} \mathrm{NH} 4 \mathrm{Cl}$ in a 4 -point pattern. Water and $\mathrm{K}_{2} \mathrm{SO}_{4}$ extracts of $\mathrm{NH}_{4}{ }^{+}-\mathrm{N}$ from these soils are significantly correlated and differ across all ecosystems by less than $5 \%$ (data not shown), so initial cores were extracted 15-20 min after injection in $40 \mathrm{ml}$ cold distilled water, by shaking for $1 \mathrm{~h}$ in a cold room $\left(4^{\circ} \mathrm{C}\right)$ and then filtering through $1.0-\mu \mathrm{m}$ glass fiber filter paper. Final cores were incubated for $24 \mathrm{~h}$ in the cold room and then extracted with the same procedure. All extracts were frozen between collection and analysis.

\section{Laboratory Analyses}

Soil moisture content and bulk density were calculated from the difference between soil fresh weight and oven-dried weight $\left(65^{\circ} \mathrm{C}\right.$ for $\left.48 \mathrm{~h}\right)$ for a known soil volume. Soil $\mathrm{pH}$ was measured on a $1: 5$ soil:water slurry after a $15-\mathrm{m}$ settling time. Extractable organic $\mathrm{C}$ (EOC) and total $\mathrm{N}$ (ETN) contents in the salt $+\mathrm{CHCl}_{3}$ ('fumigated') and salt ('non-fumigated') extracts and in the leachates were determined by oxidative combustion and infrared (EOC; Nelson and Sommers 1982) or chemiluminescence (ETN) analysis (TOC-TN autoanalyzer, Shimadzu, Kyoto, Japan). Extractable $\mathrm{NH}_{4}{ }^{+}-\mathrm{N}$ and $\mathrm{NO}_{3}{ }^{-}-\mathrm{N}$ in non-fumigated extracts and the leachates were determined colorimetrically, using automated flow analysis (Lachat autoanalyzer) and the salicylate $\left(\mathrm{NH}_{4}{ }^{+}-\mathrm{N}\right)$, and sulphanilamide $\left(\mathrm{NO}_{3}{ }^{-}-\mathrm{N}\right)$ methods (Mulvaney
1996). Extractable $\mathrm{PO}_{4}-\mathrm{P}$ in the fumigated and non-fumigated extracts was determined colorimetrically, using the malachite green method adapted for a plate reader ( $\mathrm{D}^{\prime}$ Angelo and others 2001). $\mathrm{PO}_{4}-\mathrm{P}$ in the leachates was determined on the autoanalyzer using the molybdate assay. Microbial biomass C, N, and P flushes (MBC, MBN and $\mathrm{MBP}$ ) were calculated as the difference between EOC, ETN, or $\mathrm{PO}_{4}$-P in fumigated and nonfumigated extracts. No correction factor for incomplete $\mathrm{CHCl}_{3}$-release was applied (Brookes and others 1982), because the proportion recovered has not been previously assessed for these ecosystems and because our main purpose was to compare leachate additions to control, which we assume did not alter soil $\mathrm{CHCl}_{3}$-extractability. Extractable organic nitrogen (EON) was calculated as the difference between ETN and $\mathrm{NH}_{4}{ }^{+}-\mathrm{N}+\mathrm{NO}_{3}{ }^{-}-\mathrm{N}$. The final nutrient concentration of all extracts was corrected for dilution by the water content of the sample. Subsamples of the leachates were analyzed for absorbance at $254 \mathrm{~nm}$, to calculate the specific UV absorbance (SUVA; $\mathrm{UV}_{254} / \mathrm{DOC}$ ), because SUVA is positively correlated with the chemical complexity of DOC (Weishaar and others 2003) and is therefore an indicator of microbial substrate quality. Initial and final extracts from the gross mineralization cores were diffused to capture all $\mathrm{N}$ as $\mathrm{NH}_{3}{ }^{+}$ according to Goerges and Dittert (1998), and the 'traps' (acidified glass fiber filter disks) were submitted to UC Davis Stable Isotope Facility for ${ }^{15} \mathrm{~N}$ analysis on their Elementar Vario EL Cube elemental analyzer (Elementar Analysensysteme GmbH, Hanau, Germany) interfaced to a PDZ Europa 20-20 isotope ratio mass spectrometer (Sercon Ltd., Cheshire, UK), with appropriate standards. Gross mineralization rates were calculated according to Hart and others (1994).

\section{Statistical Analyses}

We pooled the raw results and the statistical analysis, although not the experimental processing, of the two intermediate thermokarst scars, as we learned that they were similar ages after the experiment was complete. To assess the importance of leachate additions on thaw biogeochemistry across all ecosystems and within each ecosystem, we ran two-tailed matched pairs $t$ tests, comparing leachate to control, for each independent variable. Because of the small sample sizes, to minimize Type II errors, we used $P=0.1$ as the threshold for "significance" unless noted otherwise. To understand the difference between disturbed versus undisturbed ecosystem responses to leachate, we 
ran a similar two-tailed matched pairs analysis with across-groups analysis comparing disturbed MNAT and the undisturbed MNAT ecosystems (equivalent to a split-plot MANOVA). This second test provides $F$ scores for the (a) average response to disturbance for the leachate-control pairs, and (b) the disturbance $\times$ leachate response across the leachatecontrol pairs. Analyses were performed in JMP 10.0 (Cary, NJ).

\section{RESUlts}

\section{Vegetation Leachate Quality}

Leachate TOC, TN, and $\mathrm{PO}_{4}-\mathrm{P}$ concentrations from the different vegetation types varied strongly (Table 2), but differences in element ratios were driven mostly by differences in $\mathrm{PO}_{4}-\mathrm{P}$. Leachate TOC:TN ratios were similar across ecosystems (ranging between 24 and 31), with lower TOC:TN in the tall shrub leachate. In contrast to these relatively constant TOC:TN ratios, $\mathrm{PO}_{4}-\mathrm{P}$ concentrations varied enormously, with TOC: $\mathrm{PO}_{4}-\mathrm{P}$ ratios spanning from 59:1 (MNAT) to over 1000:1 (Tall
Shrub; Table 2). The leachate made from the MNAT vegetation above the thermokarst was notably high in $\mathrm{PO}_{4}-\mathrm{P}$ compared to all those from MAT communities (Table 2). The organic chemistry of the leachates also varied substantially as indicated by the SUVA values, with shrub the highest and tussock and MNAT the lowest (Table 2). The leachates alone, without soil, displayed low levels of microbial activity; over the 6 days of incubation through thaw, they respired $2.5-6.6 \%$ of the leachate $\mathrm{C}\left(0.004-0.028 \mathrm{mg} \mathrm{C} \mathrm{ml}^{-1} 6 \mathrm{~d}^{-1}\right)$. Our leachates added low levels of TOC (21.7$\left.1.4 \mathrm{~g} \mathrm{C} \mathrm{m}^{-2}\right)$, TN $\left(0.7-0.04 \mathrm{~g} \mathrm{~N} \mathrm{~m}^{-2}\right)$, and $\mathrm{PO}_{4}-\mathrm{P}$ $\left(0.13-0.003 \mathrm{~g} \mathrm{P} \mathrm{m}^{-2}\right)$ to soils at thaw. Because of the differences in vegetation chemistry, the leachates, which were added at a constant volume to reflect what would happen in situ, varied in their relative contribution to labile soil $\mathrm{C}, \mathrm{N}$, and P stocks (that is, the summed TOC, TN, or $\mathrm{PO}_{4}-\mathrm{P}$ in the microbial and soil solution, plus the $\mathrm{CO}_{2}-\mathrm{C}$ mineralized from the soils over the course of the incubation) (Table 3). From this proportional perspective, the MNAT leachate was high in TOC, TN, and $\mathrm{PO}_{4}-\mathrm{P}$; the tussock leachate was high in in TOC

Table 2. Vegetation Leachate $\mathrm{pH}, \mathrm{TOC}, \mathrm{TN}$, and $\mathrm{PO}_{4}-\mathrm{P}$ Concentration, Stoichiometry, and Specific UV Absorption at $254 \mathrm{~nm}$ (SUVA)

\begin{tabular}{|c|c|c|c|c|c|c|c|}
\hline Sourceecosystem & $\mathrm{PH}$ & $\begin{array}{l}\text { TOC } \\
\text { concentration } \\
\left(\mathrm{mg} \mathrm{C} \mathrm{L}^{-1}\right)\end{array}$ & $\begin{array}{l}\mathrm{TN} \\
\text { concentration } \\
\left(\mathrm{mg} \mathrm{N} \mathrm{L}^{-1}\right)\end{array}$ & $\begin{array}{l}\mathrm{PO}_{4}-\mathrm{P} \\
\text { concentration } \\
\left(\mathrm{mg} \mathrm{P} \mathrm{L}^{-1}\right)\end{array}$ & $\begin{array}{l}\text { TOC:TN } \\
\text { leachate }\end{array}$ & $\begin{array}{l}\text { TOC: } \\
\mathrm{PO}_{4}-\mathrm{P} \\
\text { leachate }\end{array}$ & 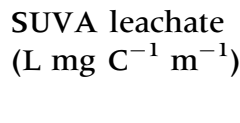 \\
\hline Undisturbed MNAT & 4.83 & 246.00 & 8.02 & 4.19 & $31: 1$ & $59: 1$ & 0.90 \\
\hline Heath & 5.00 & 88.84 & 3.06 & 0.28 & $29: 1$ & $321: 1$ & 1.62 \\
\hline Tall shrub & 6.16 & 143.78 & 6.02 & 0.14 & $24: 1$ & 1054:1 & 4.49 \\
\hline Tussock & 4.06 & 873.80 & 29.44 & 5.33 & $30: 1$ & $164: 1$ & 0.39 \\
\hline
\end{tabular}

Table 3. Summed Labile C, N, and P Pools in the Control Cores (Microbial and Soil Solution C, N, or P, Plus $\mathrm{CO}_{2}-\mathrm{C}$ Mineralized During the Incubation) and the Added Vegetation Leachate TOC, TN, and $\mathrm{PO}_{4}-\mathrm{P}$ as a Percentage of These Control Core Pools

\begin{tabular}{|c|c|c|c|c|c|c|c|}
\hline Tundra type & Ecosystem & $\begin{array}{l}\text { Summed } \\
\text { soil labile C } \\
\text { pools (control) } \\
\left(\mu \mathrm{g} \mathrm{g}^{-1} \mathrm{dw}\right)\end{array}$ & $\begin{array}{l}\text { Leachate } \\
\text { TOC } \\
\text { relative } \\
\text { to summed } \\
\text { labile } \\
\text { C pools }(\%)\end{array}$ & $\begin{array}{l}\text { Summed } \\
\text { soil labile } \\
\mathrm{N} \text { pools } \\
(\text { control) } \\
\left(\mu \mathrm{g} \mathrm{g}^{-1} \mathrm{dw}\right)\end{array}$ & $\begin{array}{l}\text { Leachate } \\
\text { TN relative } \\
\text { to summed } \\
\text { labile } \mathrm{N} \\
\text { pools }(\%)\end{array}$ & $\begin{array}{l}\text { Summed } \\
\text { soil labile } \\
\text { P pools } \\
\text { (control) } \\
\left(\mu g^{-1} \mathrm{dw}\right)\end{array}$ & $\begin{array}{l}\text { Leachate } \\
\mathrm{PO}_{4}-\mathrm{P} \\
\text { relative to } \\
\text { summed } \\
\text { labile } \mathrm{P} \\
\text { pools }(\%)\end{array}$ \\
\hline \multirow[t]{5}{*}{ Thermokarst } & Recent mineral & 51 & 248 & 6 & 38 & 2 & 78 \\
\hline & Recent rafts & 1064 & 46 & 129 & 14 & 25 & 31 \\
\hline & Intermediate & 4755 & 16 & 319 & 7 & 70 & 18 \\
\hline & Old & 4396 & 26 & 272 & 13 & 58 & 35 \\
\hline & Undisturbed & 3569 & 28 & 185 & 18 & 47 & 52 \\
\hline \multirow[t]{3}{*}{ Non-thermokarst } & Heath & 962 & 6 & 66 & 3 & 11 & 2 \\
\hline & Tall shrub & 3404 & 23 & 261 & 13 & 56 & 1 \\
\hline & Tussock & 14,322 & 22 & 1367 & 8 & 73 & 33 \\
\hline
\end{tabular}


and $\mathrm{PO}_{4}-\mathrm{P}$ but low in $\mathrm{TN}$; the tall shrub leachate was high in TOC and TN but low in $\mathrm{PO}_{4}-\mathrm{P}$; and the heath leachate was very low in TOC, TN, and $\mathrm{PO}_{4}-\mathrm{P}$ (Table 3).

\section{Ecosystem Pool and Process Responses to Leachate}

The only element that showed significant changes in microbial pools in response to leachate additions was phosphorus. Across all the vegetated ecosystems, adding leachates increased the microbial biomass $\mathrm{P}$ flush; the increases were statistically significantly at $P<0.1$ in the recent rafts, the old thermokarst, and the heath (Table 4; Figure 1). In these systems, essentially all the $\mathrm{PO}_{4}$-P that was added in the leachate was immobilized into the microbial biomass. The response in the recently disturbed mineral soil was different than in the vegetated ecosystems; extractable $\mathrm{PO}_{4}-\mathrm{P}$ increased with leachate addition but the MBP flush did not (Table 4; Figure 1).

Neither C nor N cycling showed any measurable microbial response to leachate additions; this lack of response was consistent across all the measures of $\mathrm{C}$ and $\mathrm{N}$ dynamics and in all the soils (Table 4; Figure 1). In response to adding dissolved TOC and $\mathrm{TN}$ in the leachate, EOC and ETN pools increased and this occurred in all ecosystems, significantly so for EOC in the recent mineral soils and for ETN and EON in the tall shrub soils (Table 4; Figures 1 and 2). Neither of the measured $\mathrm{C}$ or $\mathrm{N}$ cycling rates responded to leachate additions-that is soil respiration (C mineralization) and gross $\mathrm{N}$ mineralization (ammonification) (Table 4; Figure 3).

When the paired cores are averaged across disturbed MNAT and undisturbed MNAT ecosystems (that is regardless of ecosystem or leachate addition), the MBC flush was reduced in disturbed relative to undisturbed ecosystems, but the interaction of disturbance with leachate was not important: leachate response in soils and microorganisms was not affected by disturbance per se (Table 4).

\section{Discussion}

We proposed two alternate hypotheses about how tundra soil might respond to leachates during the critical thaw period, recognizing that these represented endpoints along a spectrum of possible responses. Either leachate would provide needed substrate to microbes, or the nutrient additions would be swamped by high background nutrient pools. Instead we found a surprising response that did not fit cleanly along this gradient. Rather than stimulating microbial activity generally (either to accelerate mineralization or immobilization), there was a much more specific response: microorganisms ignored the $\mathrm{C}$ and $\mathrm{N}$, and selectively immobilized $\mathrm{PO}_{4}$-P from thaw leachate.

The selective $\mathrm{PO}_{4}-\mathrm{P}$ uptake at thaw raises several important questions: what is the mechanism by

Table 4. Two-Tailed Matched Pairs Statistics ( $P$ values) for the Leachate Effect on Independent Variables Across All Ecosystems and for Each Ecosystem

\begin{tabular}{|c|c|c|c|c|c|c|c|c|c|c|c|}
\hline & & \multirow{2}{*}{\multicolumn{2}{|c|}{$\begin{array}{l}\text { Heath Tall } \\
\text { shrub }\end{array}$}} & \multirow{2}{*}{ Tussock } & \multicolumn{4}{|c|}{ Disturbed (thermokarst) } & \multicolumn{3}{|c|}{ Undisturbed Disturbance Leachate $\times$} \\
\hline & ecosystems & & & & $\begin{array}{l}\text { Recen } \\
\text { miner }\end{array}$ & Rece & Inte & Old & & & \\
\hline & $\mathbf{P}$ & $\mathrm{P}$ & $\mathrm{P}$ & $\mathbf{P}$ & $\mathrm{P}$ & $\mathbf{P}$ & $\mathbf{P}$ & $\mathrm{P}$ & $\mathrm{P}$ & $\mathbf{P}$ & $\mathrm{P}$ \\
\hline $\mathrm{MBC}$ & 1.0 & 0.4 & 0.5 & 0.8 & 0.4 & 0.7 & 0.4 & 0.8 & 0.8 & 0.09 & 0.9 \\
\hline $\mathrm{MBN}$ & 0.4 & 1.0 & 0.2 & 0.5 & 0.9 & 0.2 & 0.6 & 0.5 & 0.2 & 0.6 & 0.2 \\
\hline MBP & 0.003 & 0.07 & 0.9 & 0.2 & 0.1 & 0.09 & 0.4 & 0.05 & 0.8 & 0.5 & 0.2 \\
\hline $\mathrm{EOC}$ & 0.04 & 0.5 & 0.2 & 0.2 & 0.05 & 0.7 & 0.3 & 0.2 & 0.4 & 0.9 & 0.9 \\
\hline ETN & 0.098 & 0.5 & 0.05 & 0.5 & 0.9 & 0.3 & 0.4 & 0.7 & 0.4 & 0.4 & 0.2 \\
\hline $\mathrm{PO}_{4}-\mathrm{P}$ & 0.2 & 0.9 & 0.4 & 0.9 & 0.05 & 0.5 & 0.4 & 0.1 & 0.8 & 0.9 & 0.6 \\
\hline $\mathrm{CO}_{2}$ & 0.9 & 0.7 & 0.2 & 0.3 & 0.2 & 0.2 & 0.3 & 0.6 & 0.8 & 0.8 & 1.0 \\
\hline GM & 0.8 & 0.4 & 0.4 & 0.1 & nd & 0.3 & 0.9 & 0.3 & 0.3 & 0.5 & 0.4 \\
\hline EON & 0.5 & 0.5 & 0.04 & 0.5 & 0.6 & 0.3 & 0.2 & 0.4 & 0.4 & 0.6 & 0.9 \\
\hline $\mathrm{NO}_{3}-\mathrm{N}$ & 0.2 & 0.7 & 0.9 & 0.4 & 0.1 & 0.4 & 0.8 & 0.3 & 0.8 & 0.5 & 0.5 \\
\hline $\mathrm{NH}_{4}-\mathrm{N}$ & 0.5 & 0.5 & 0.3 & 0.1 & 0.2 & 0.8 & 0.3 & 0.6 & 0.4 & 0.2 & 0.5 \\
\hline
\end{tabular}



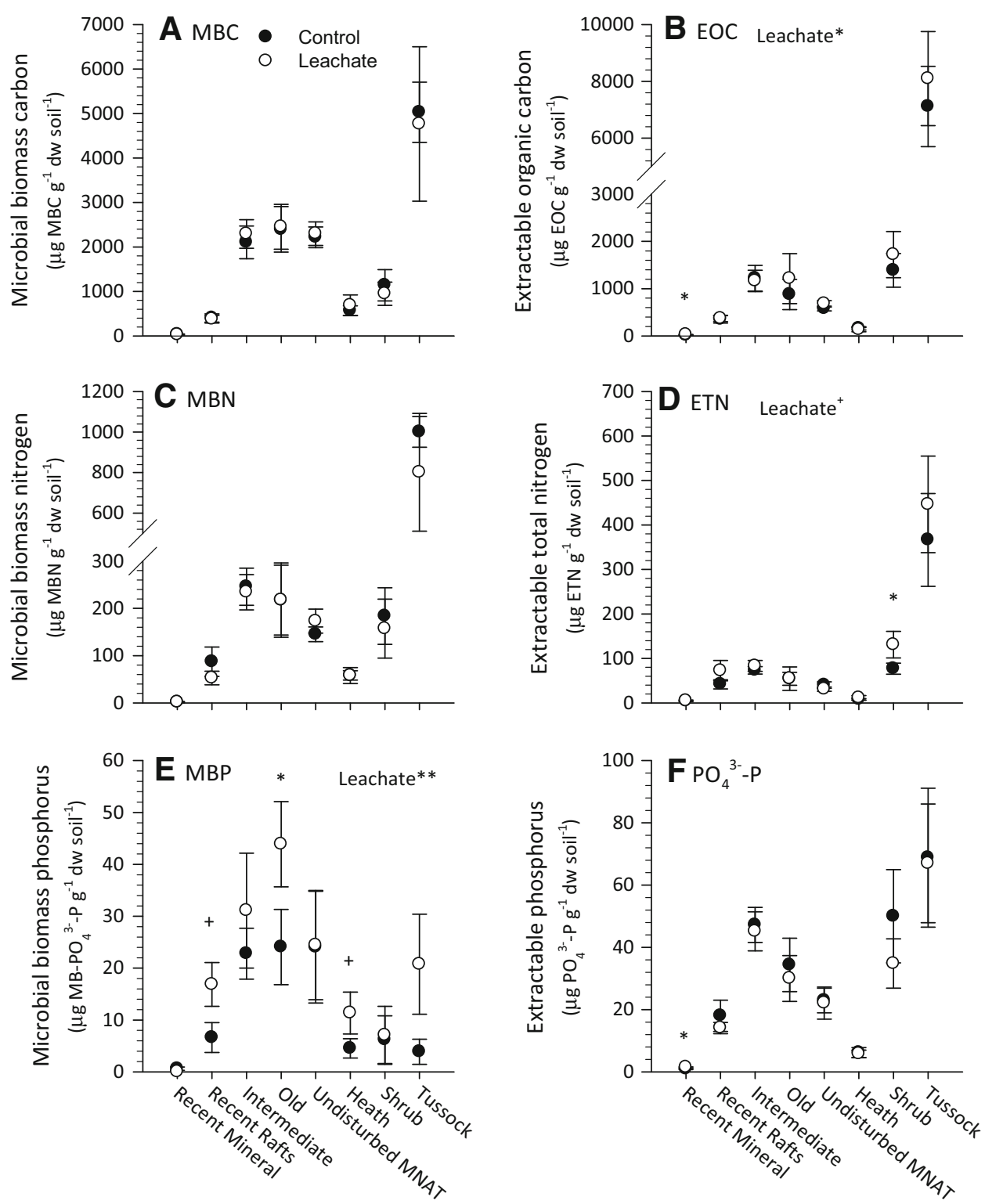

Figure 1. Biogeochemical pools in disturbed (recent mineral, recent rafts, intermediate and old) and undisturbed (MNAT, heath, shrub, tussock) tundra ecosystems after a manipulated thaw with and without leachate addition: A soil microbial biomass carbon, $\mathbf{B} \mathrm{K}_{2} \mathrm{SO}_{4}$-extractable organic carbon, $\mathbf{C}$ microbial biomass nitrogen, $\mathbf{D} \mathrm{K}_{2} \mathrm{SO}_{4}$-extractable total nitrogen, $\mathbf{E}$ microbial biomass phosphate, and $\mathbf{F ~} \mathrm{NaHCO}_{3}$-extractable phosphate. Open circles are leachate-added, black circles are control (water-added). Error bars are \pm one standard error. Significant two-tailed matched pairs statistics for leachate effect on each ecosystem and across all ecosystems are indicated by symbols: ${ }^{+} P<0.1,{ }^{*} P<0.05, * * P<0.01$.

which microbes selectively extract $\mathrm{P}$ from the organic compounds in the leachate? Is this driven by microbial needs (that is, $\mathrm{P}-$, but not $\mathrm{C}$ - or $\mathrm{N}$-limitation), by the nature of the material $\left(\mathrm{PO}_{4}-\mathrm{P}\right.$ is accessible but the core organic structures are otherwise not bioavailable) or by the environmental conditions at thaw (the low temperature inhibits microbes from taking up or catabolising the leachates but not from scavenging the $\left.\mathrm{PO}_{4}-\mathrm{P}\right)$ ?
What is the significance to overall ecosystem function of this early season selective P harvesting?

\section{Leachate Quality, Nutrient Limitation, and Microbial Opportunism}

Leachate pulses are common to most ecosystems with seasonal snowmelt or precipitation, yet we know very little about the nature of these inputs. 

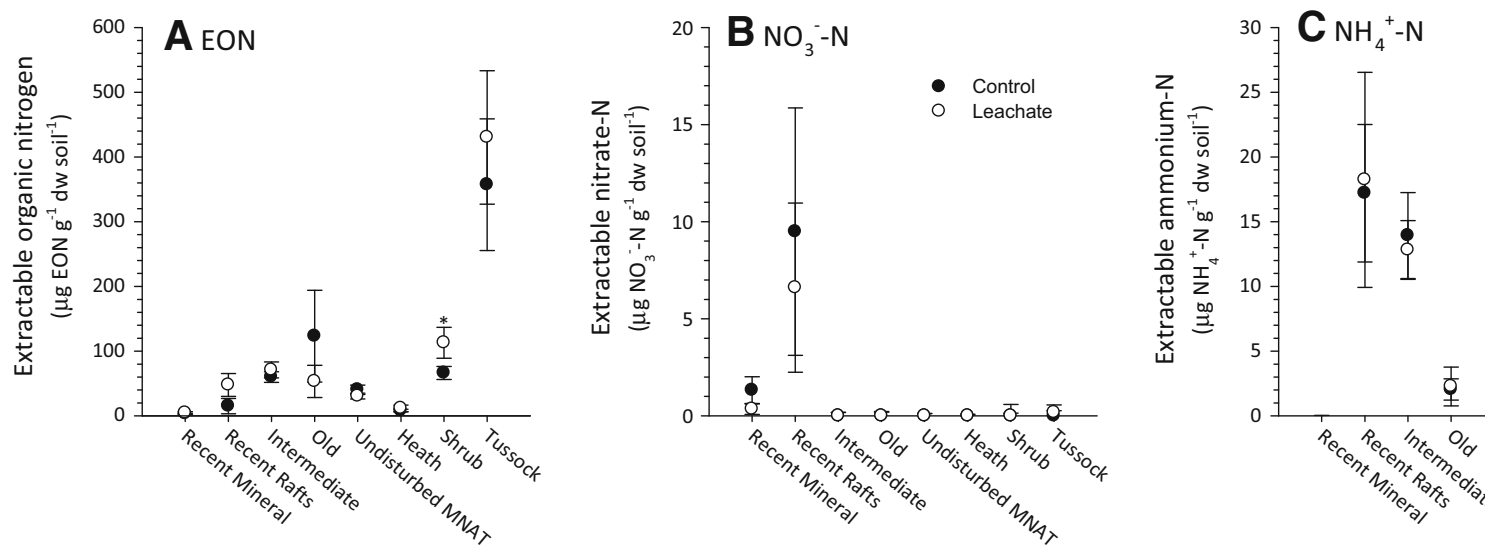

Figure 2. Nitrogen pools in disturbed and undisturbed tundra ecosystems after a manipulated thaw with and without leachate addition: $\mathbf{A ~} \mathrm{K}_{2} \mathrm{SO}_{4}$ extractable organic nitrogen, $\mathbf{B ~} \mathrm{K}_{2} \mathrm{SO}_{4}$ extractable nitrate- $\mathrm{N}$, $\mathbf{C}$ and $\mathrm{K}_{2} \mathrm{SO}_{4}$ extractable ammonium-N. Open circles are leachate-added, and black circles are control (water-added). Error bars are \pm one standard error. $* p<0.05$.
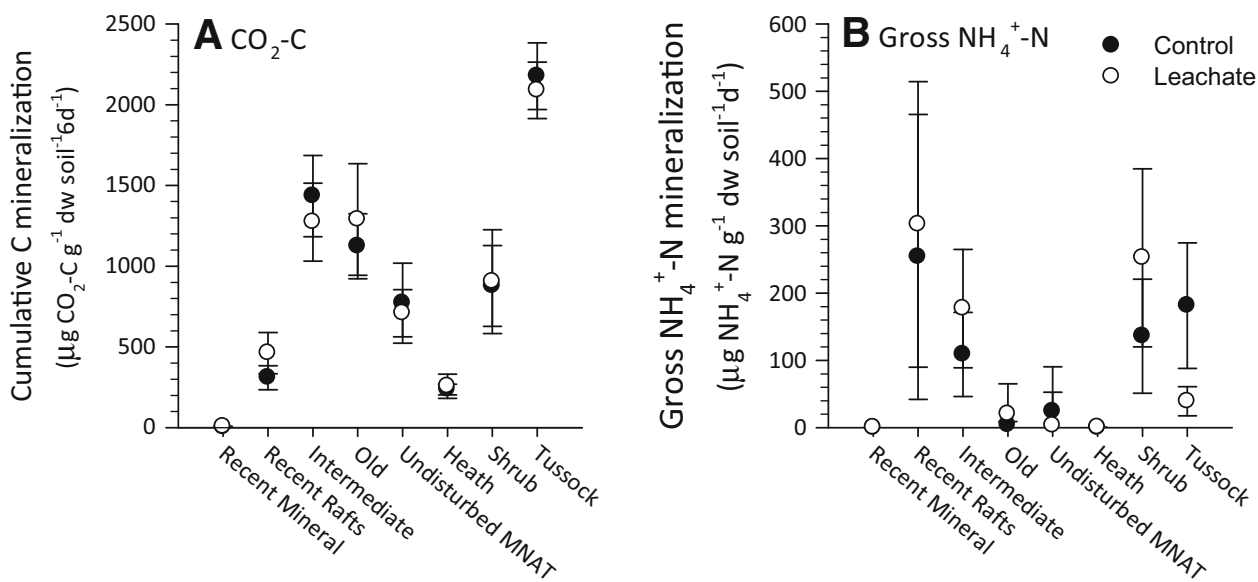

Figure 3. Microbial activity in disturbed and undisturbed tundra ecosystems during a manipulated thaw with and without leachate addition: A soil cumulative $\mathrm{CO}_{2}-\mathrm{C}$ mineralization over a 6-day thaw, and $\mathbf{B}$ gross $\mathrm{NH}_{4}{ }^{+}-\mathrm{N}_{\text {mineralization at the }}$ end of a 6-day thaw. Open circles are leachate-added, and black circles are control (water-added). Error bars are \pm one standard error.

Our leachate additions of TOC, TN, and $\mathrm{PO}_{4}$-P were small, but they could be substantial relative to the pools of labile nutrients that directly drive microbial activity. We estimated this total labile pool as the pre-leachate EOC, ETN, or $\mathrm{PO}_{4}-\mathrm{P}$ in the microbial biomass flush plus the soil extractable pool, and for $\mathrm{C}$, included the mineralized $\mathrm{CO}_{2}$. On average, the leachate addition was equivalent to $50 \%$ of the labile C, $14 \%$ of the $\mathrm{N}$, and $31 \%$ of the $\mathrm{PO}_{4}-\mathrm{P}$; the leachates were, thus, relatively $\mathrm{PO}_{4}$-P-rich. We did not measure available organic $\mathrm{P}$ pools in the leachates or in these soils, which are often larger than inorganic $P$ pools in tundra ecosystems (Giblin and others 1991; Gough and others 2002; Giesler and others 2012), so we are undoubtedly underestimating the proportion of $\mathrm{P}$ in both, and therefore may be over- or underestimating the relative proportion of $\mathrm{P}$ in the leachate compared to the soil. With this in mind, across the landscape, leachate values varied strongly, as both the proportion of pre-leachate labile nutrient pools $(3-248 \%)$ and the stoichiometry of the addition (Table 3). The TOC:TN and TOC: $\mathrm{PO}_{4}-\mathrm{P}$ ratios of the added leachates were low (that is, low TOC), given the $\mathrm{C}: \mathrm{N}$ and $\mathrm{C}: \mathrm{P}$ of litter in arctic ecosystems, which falls in the range of 50-150 (C:N) and 11003500 (C:P) (Aerts and others 2012), indicating that vegetation and litter disproportionately release $\mathrm{TN}$ and $\mathrm{PO}_{4}-\mathrm{P}$ with snowpack thaw, assuming that our 
leachate preparation adequately mimicked this process. Microbial acquisition of nutrients has been modeled in terms of critical ratios (Sterner and Elser 2002; Manzoni and others 2008) that are based on microbial nutrient uptake to support growth; critical ratios are regulated by the stoichiometry of $\mathrm{C}: \mathrm{N}: \mathrm{P}$ in proteins, DNA, ATP, and phospholipids. Although the leachates were relatively $\mathrm{TN}$-rich compared to TOC (they had a lower TOC:TN than soil extractable pools), they were even relatively more $\mathrm{PO}_{4}$-P-rich, frequently containing more $\mathrm{PO}_{4}-\mathrm{P}$ than TN relative to extractable soil pools (Table 3). MBN:MBP and MBC:MBP values were about 5-20 $(\mathrm{N}: \mathrm{P})$ and about $100-400(\mathrm{C}: \mathrm{P})$ in the thermokarst and over 1000 in the shrubby thermokarst and outside the thermokarst, large ranges that are consistent with fluctuating microbial stoichiometry at thaw (Buckeridge and Grogan 2010). However, in most of the cores, MBC:MBP and MBN:MBP ratios declined with the addition of leachate. Selective $\mathrm{PO}_{4}$-P uptake despite relatively low amounts of ETN further implies that soil microbes are either strongly $P$ limited during thaw or strongly opportunistic about pulsed nutrient acquisition.

Microbes may be opportunistic when it comes to nutrient uptake. In soil, for microbes to access $\mathrm{P}$, it has to be hydrolyzed off a phosphate ester with phosphatase, which is then readily available for microbial uptake. Acquiring $\mathrm{C}$ and $\mathrm{N}$ is more biochemically involved than acquiring $\mathrm{P}$, requiring more extracellular enzymes to break up organic polymers and release $\mathrm{C}$ - and $\mathrm{N}$-containing monomers that can be taken up, and then complex cellular pathways are required to metabolize those monomers. By adding leachates, we provided a substantial pool of inorganic $\mathrm{N}$ and $\mathrm{P}$ that bypassed the extracellular enzyme release stage, with the inorganic $\mathrm{N}: \mathrm{P}$ ratio of about 0.5 . Therefore, the preferential uptake of $\mathrm{P}$ over $\mathrm{N}$ in typically $\mathrm{N}$-limited systems may imply that $\mathrm{N}$ processing is more temperature sensitive, preventing $\mathrm{N}$ uptake and allowing $\mathrm{P}$ uptake for future use. However, very cold soils have temperature-compromised diffusion rates, such that nutrients are not as available as their concentrations imply, and there was simply more inorganic $\mathrm{P}$ available in these soils, and more so after leachate additions. P may not have been limiting growth or activity; however, the ability of microbes to store $\mathrm{P}$ as polyphosphates for future use (that is, luxury consumption) appears to be widespread (Achbergerova and Nahalka 2011), and a common mechanism to deal with environmental stress and an inconsistent nutrient supply: typical life in tundra soil. Therefore, variation in microbial $\mathrm{P}$ uptake across the landscape may be in part a result of the physiological capacities of the different microbial communities in these ecosystems (Wallenstein and others 2007). Regardless of mechanism, this $\mathrm{P}$ store in the thaw microbial biomass may be an important microbial repository or mycorrhizal exchange of $\mathrm{P}$ for plants at a time of year when they cannot access $\mathrm{P}$ from frozen mineral soil.

A number of recent studies recognize that tundra ecosystems may be $\mathrm{N}$ and $\mathrm{P}$ co-limited, or just $\mathrm{P}$ limited (Giesler and others 2012; Zamin and Grogan 2012; Sundqvist and others 2014). Our leachate addition did not allow us to characterize nutrient limitation per se, and we did not see final evidence of nutrient limitation (that is, increase in $\mathrm{MBC}$ or microbial $\mathrm{CO}_{2}$ ). However, our experiment was short, with temperature conditions that may not support rapid anabolism, and microbial uptake of $\mathrm{P}$ may be a precursor to microbial growth. Although the MBP flush in all vegetated ecosystems responded positively to leachate additions (Figure 1), this response was strong and significant $(P<0.1)$ in the tundra rafts of the recent thermokarst, the old thermokarst, and the heath ecosystem (Table 4). These three leachates had the lowest TOC: $\mathrm{PO}_{4}-\mathrm{P}$ ratios, and the MNT leachate had a high $\mathrm{PO}_{4}-\mathrm{P}$ concentration. The response from the Heath ecosystem was surprising; given the relatively low $\mathrm{PO}_{4}-\mathrm{P}$ addition provided by the Heath leachate, this ecosystem may be N and P co-limited (Gough and others 2002), and perhaps more P limited at thaw. N and $\mathrm{P}$ availability in soils fluctuate seasonally (Weintraub and Schimel 2005; Buckeridge and Grogan 2010; Weintraub 2011), such that N and P limitation of microbes and plants may be uncoupled (Sundqvist and others 2014) and asynchronously dominant throughout the year. $\mathrm{P}$ availability in permafrost soils is largely driven by recycling of soil and plant litter organic $\mathrm{P}$ (Chapin and Bloom 1976; Giblin and others 1991); microbial nutrient limitation may alter plant nutrient limitation, as the soil microbial biomass is a large repository of available nutrients, and microbial turnover (death and release of cytoplasmic nutrients) can offer pulses of labile nutrients for plant uptake throughout the year (Schimel and others 2007). Whether limitations to microbial growth or opportunism control microbial uptake, our results suggest that thaw is an important period of microbial $\mathrm{P}$ retention from decaying and physically distressed plant litter under a melting snowpack. 


\section{The Impact of Disturbance on Leachate Response}

Disturbed ecosystems are expected to retain limiting nutrients strongly, reducing the export of these nutrients (Vitousek and Reiners 1975). This theory was developed to consider net ecosystem losses over successional time and is based on the vegetation recovering and regrowing, taking up nutrients and supplying $\mathrm{C}$ to soil microbes that can immobilize nutrients. More temporally refined models have suggested that disturbed ecosystems lose their $\mathrm{N}$-P synchrony upon disturbance, as $\mathrm{N}$ is more readily exported than $\mathrm{P}$, so that ecosystem recovery is associated with fluctuating microbial and plant stoichiometric constraints and $\mathrm{N}$ and $\mathrm{P}$ limitation (Rastetter and others 2013). Therefore, our second hypothesis was that we would see larger nutrient retention after initial disturbance and that this would diminish as ecosystems recover and organic matter accumulates. Specifically, we envisioned early retention of $\mathrm{C}$ in the recently disturbed soils without an organic horizon, and high retention of $\mathrm{N}$ and $\mathrm{P}$ to compensate for enhanced aboveground biomass in the intermediate stages of recovery (Pizano and others 2014). Instead we saw that thaw leachate did not promote $\mathrm{C}$ or $\mathrm{N}$ retention by microbes in recently disturbed ecosystems, that all vegetated ecosystems retained $\mathrm{P}$, and that this landscape-wide pattern was not shifted by disturbance. Thaw is in itself a stressful period for soil microorganisms. It is possible that this annually repeated disturbance masks biogeochemical and microbial differences that may exist in response to long-term disturbance history.

\section{Thaw Leachate, Winter Decomposition, and DOM Export}

We collected vegetation and litter to make leachate, while the material was frozen during the winter. Yet, although material is frozen, decomposition continues through the winter-in fact winter mass loss can dominate annual litter mass loss (Hobbie and Chapin 1996), and control long-term species mass loss patterns (McLaren and others unpublished). However, it is unclear what the patterns and processes that drive winter mass loss are, and how this may affect the chemistry of litter to be leached at snowmelt. By adding the leachate from this vegetation to local or downslope (thermokarst) soils, we are providing estimates of the potential for retention or export of the leachate $\mathrm{C}, \mathrm{N}$, and $\mathrm{P}$ from over-winter microbial decomposition and physical nutrient release, assuming that surface (that is,
0-5 cm) soil solution pools are available for export as ecosystems thaw (Hobbie and Chapin 1996). The quantity of $\mathrm{C}, \mathrm{N}$, and $\mathrm{P}$ in our leachates was, not surprisingly, higher than that typically recorded downstream (Balcarczyk and others 2009; Townsend-Small and others 2011). We believe that our leachates should reasonably mimic the natural leachates in upland terrestrial systems, similar to what would occur under a saturated snowpack during thaw. This suggests that local soil receives a much higher nutrient load at thaw than the already high load deposited in aquatic systems at this time, and that only the $\mathrm{P}$ is retained from these leachates. We suspect that the $\mathrm{C}$ and $\mathrm{N}$ in these leachates would have a much stronger impact on microbial activity at riparian systems or after sufficient photolysis en route to riparian systems (Yavitt and Fahey 1986), and may have some impact on downstream terrestrial systems where thaw water collects for longer periods of time under warmer temperatures (Duan and others 2014). As a result of the strong retention of $\mathrm{P}$, we conclude that downstream export from vegetation and litter leachate is dominated by $\mathrm{C}$ and $\mathrm{N}$, except for the minimally processed exports from the recently disturbed mineral soils.

\section{Conclusions}

Leachate made from frozen vegetation and litter in four Arctic ecosystems was added to frozen soil cores from disturbed and undisturbed ecosystems and incubated through thaw. We hypothesized (a) that the leachate $\mathrm{C}$ and $\mathrm{N}$ would stimulate microbial activity at thaw and (b) that the response would be stronger in recently disturbed systems where pools or organic material have been stripped away than later in system recovery when organic soil layers were recovering. Instead of the expected positive $\mathrm{C}$ and $\mathrm{N}$ response, all vegetated soils responded to leachate with enhanced microbial $\mathrm{P}$ uptake. $\mathrm{C}$ and $\mathrm{N}$ remained in solution at the end of thaw, and gross $\mathrm{N}$ mineralization and microbial respiration were not stimulated by leachate addition. The selective uptake of $\mathrm{PO}_{4}-\mathrm{P}$ was not associated with disturbed or undisturbed ecosystems, although microbes in the recently disturbed, bare mineral soil did not respond positively to $\mathrm{PO}_{4}$-P like the vegetated ecosystems. It remains unclear whether the selective $\mathrm{PO}_{4}-\mathrm{P}$ uptake in the vegetated systems reflects limitation, and as such a microbial preference for $\mathrm{P}$ over $\mathrm{C}$ or $\mathrm{N}$ at thaw, or, alternatively, the capacity of microbes to access $\mathrm{PO}_{4}-\mathrm{P}$ more than $\mathrm{C}$ or $\mathrm{N}$ at this time of year and store it for future use. 


\section{ACKNOWLEDGMENTS}

The material presented here was supported by the U.S. National Science Foundation under collaborative Grant ARC-0806451. We thank the staff of the Toolik Field Station and $\mathrm{CH} 2 \mathrm{M}$-Hill Polar Services for logistical support. Ken Marchus, Kelsey Dowdy, Alyssa Raley, and Matt Mass provided important assistance in the laboratory, and Sarah Hobbie and two anonymous reviewers gave valuable input on the manuscript.

\section{OPEN ACCESS}

This article is distributed under the terms of the Creative Commons Attribution 4.0 International License (http://creativecommons.org/licenses/by/ 4.0/), which permits unrestricted use, distribution, and reproduction in any medium, provided you give appropriate credit to the original author(s) and the source, provide a link to the Creative Commons license, and indicate if changes were made.

\section{REFERENCES}

Achbergerova L, Nahalka J. 2011. Polyphosphate-an ancient energy source and active metabolic regulator. Microb Cell Fact 10:63.

Aerts R, Callaghan TV, Dorrepaal E, van Logtestijn RSP, Cornelissen JHC. 2012. Seasonal climate manipulations have only minor effects on litter decomposition rates and $\mathrm{N}$ dynamics but strong effects on litter P dynamics of sub-arctic bog species. Oecologia 170:809-19.

Amon RMW, Rinehart AJ, Duan S, Louchouarn P, Prokushkin A, Guggenberger G, Bauch D, Stedmon C, Raymond PA, Holmes RM, McClelland JW, Peterson BJ, Walker SA, Zhulidov AV. 2012. Dissolved organic matter sources in large Arctic rivers. Geochim Cosmochim Acta 94:217-37.

Armstrong A, Holden J, Luxton K, Quinton JN. 2012. Multiscale relationship between peatland vegetation type and dissolved organic carbon concentration. Ecol Eng 47:182-8.

Balcarczyk K, Jones J, Jaffe R, Nagamitsu M. 2009. Stream dissolved organic matter bioavailability and composition in watersheds underlain with discontinuous permafrost. Biogeochemistry 94:255-70.

Brookes PC, Powlson DS, Jenkinsen DS. 1982. Measurement of microbial biomass phosphorus in soil. Soil Biol Biochem 14:319-29.

Bowden WB, Gooseff MN, Balser A, Green A, Peterson BJ, Bradford J. 2008. Sediment and nutrient delivery from thermokarst features in the foothills of the North Slope, Alaska: potential impacts on headwater stream ecosystems. J Geophys Res 113:G02026.

Buckeridge KM, Grogan P. 2010. Deepened snow increases late thaw biogeochemical pulses in mesic low arctic tundra. Biogeochemistry 101:105-21.

Buckeridge KM, Banerjee S, Siciliano SD, Grogan P. 2013. The seasonal pattern of soil microbial community structure in mesic low arctic tundra. Soil Biol Biochem 65:338-47.
Chapin FS, Bloom A. 1976. Phosphate absorption—adaptation of tundra graminoids to a low-temperature, low phosphorus environment. Oikos 27:111-21.

Clemmensen KE, Michelsen A, Jonasson S, Shaver GR. 2006. Increased ectomycorrhizal fungal abundance after long-term fertilization and warming of two arctic tundra ecosystems. New Phytologist 171:391-404.

Cleveland CC, Neff JC, Townsend AR, Hood E. 2004. Composition, dynamics, and fate of leached dissolved organic matter in terrestrial ecosystems: results from a decomposition experiment. Ecosystems 7:275-85.

Crump BC, Kling GW, Bahr M, Hobbie JE. 2003. Bacterioplankton community shifts in an arctic lake correlate with seasonal changes in organic matter source. Appl Environ Microbiol 69:2253-68.

D'Angelo E, Crutchfield J, Vandiviere M. 2001. Rapid, sensitive, microscale determination of phosphate in water and soil. $\mathrm{J}$ Environ Qual 30:2206-9.

Deslippe JR, Hartmann M, Mohn WW, Simard SW. 2011. Longterm experimental manipulation of climate alters the ectomycorrhizal community of Betula nana in Arctic tundra. Glob Change Biol 17:1625-36.

Duan S, Delaney-Newcomb K, Kaushal SS, Findlay SEG, Belt KT. 2014. Potential effects of leaf litter on water quality in urban watersheds. Biogeochemistry 121:61-80.

Edwards KA, McCulloch J, Kershaw GP, Jefferies RL. 2006. Soil microbial and nutrient dynamics in a wet Arctic sedge meadow in late winter and early spring. Soil Biol Biochem 38:2843-51.

Fierer N, Schimel JP. 2003. A proposed mechanism for the pulse in carbon dioxide production commonly observed following the rapid rewetting of a dry soil. Soil Sci Soc Am J 67:798-805.

Giblin AE, Nadelhoffer KJ, Shaver GR, Laundre JA, McKerrow AJ. 1991. Biogeochemical diversity along a riverside toposequence in Arctic Alaska. Ecol Monogr 61:415-35.

Giesler R, Esberg C, Lagerström A, Graae BJ. 2012. Phosphorus availability and microbial respiration across different tundra vegetation types. Biogeochemistry 108:429-45.

Goerges T, Dittert K. 1998. Improved diffusion technique for $15 \mathrm{~N}: 14 \mathrm{~N}$ analysis of ammonium and nitrate from aqueous samples by stable isotope spectrometry. Commun Soil Sci Plant Anal 29:361-8.

Gooseff MN, Balser A, Bowden WB, Jones JB. 2009. Effects of hillslope thermokarst in Northern Alaska. Eos Trans Am Geophys Union 90:29-31.

Gough L, Wookey P, Shaver G. 2002. Dry heath arctic tundra responses to long-term nutrient and light manipulation. Arct Antarct Alp Res 34:211-18.

Hart SC, Stark JM, Davidson EA, Firestone MK. 1994. Nitrogen mineralization, immobilization, and nitrification. In: Bigham JM, Ed. Methods of soil analysis. Madison: Soil Science Society of America. p 985-1018.

Hinzman LD, Kane DL, Gieck RE, Everett KR. 1991. Hydrologic and thermal properties of the active layer in the Alaskan Arctic. Cold Rag Sci Technol 19:95-110.

Hobbie S, Chapin FS. 1996. Winter regulation of tundra litter carbon and nitrogen dynamics. Biogeochemistry 35:327-38.

Hobbie SE, Gough L, Shaver GR. 2005. Species compositional differences on different-aged glacial landscapes drive contrasting responses of tundra to nutrient addition. J Ecol 93:770-82. 
Jonasson S, Michelsen A, Schmidt IK, Nielsen EV, Callaghan TV. 1996. Microbial biomass C, N and P in two arctic soils and responses to addition of NPK fertilizer and sugar: implications for plant nutrient uptake. Oecologia 106:507-15.

Judd KE, Kling GW. 2002. Production and export of dissolved C in arctic tundra mesocosms: the roles of vegetation and water flow. Biogeochemistry 60:213-34.

Judd KE, Crump BC, Kling GW. 2006. Variation in dissolved organic matter controls bacterial production and community composition. Ecology 87:2068-79.

Lantz TC, Kokelj SV. 2008. Increasing rates of retrogressive thaw slump activity in the Mackenzie Delta region, N.W.T., Canada. Geophys Res Lett 35:L06502.

Mack MC, Schuur EAG, Bret-Harte MS, Shaver GR, Chapin FS. 2004. Ecosystem carbon storage in arctic tundra reduced by long-term nutrient fertilization. Nature 431:440-3.

Manzoni S, Jackson RB, Trofymow JA, Porporato A. 2008. The global stoichiometry of litter nitrogen mineralization. Science 321:684-6.

McMahon SK, Wallenstein MD, Schimel JP. 2009. Microbial growth in Arctic tundra soil at $-2^{\circ} \mathrm{C}$. Environ Microbiol Rep 1:162-6.

Michaelson GJ, Ping CL, Kling GW, Hobbie JE. 1998. The character and bioactivity of dissolved organic matter at thaw and in the spring runoff waters of the arctic tundra north slope, Alaska. J Geophys Res Atmos 103:28939-46.

Mulvaney RL. 1996. Nitrogen-inorganic forms. In: Sparks DL, Ed. Methods of soil analysis: chemical methods. Madison: Soil Science Society of America and American Society of Agronomy. p 1123-84.

Nelson DW, Sommers LE. 1982. Total carbon, organic carbon, and organic matter. In: Sparks DL, Ed. Methods of soil analysis. Part 3. Chemical methods. 2nd edn. Madison: Soil Science Society of America and American Society of Agronomy. p 539-79.

Pizano C, Barón AF, Schuur EAG, Crummer KG, Mack MC. 2014. Effects of thermo-erosional disturbance on surface soil carbon and nitrogen dynamics in upland arctic tundra. Environ Res Lett 9:075006.

Qualls ARG, Haines BL, Swank WT, Tyler SW. 2002. Retention of soluble organic nutrients by a forested ecosystem. Biogeochemistry 61:135-71.

Rastetter EB, Yanai RD, Thomas RQ, Vadeboncoeur MA, Fahey TJ, Fisk MC, Kwiatkowski BL, Hamburg SP. 2013. Recovery from disturbance requires resynchronization of ecosystem nutrient cycles. Ecol Appl 23:621-42.

Schimel JP, Clein JS. 1996. Microbial response to freeze-thaw cycles in tundra and taiga soils. Soil Biol Biochem 28:1061-6.

Schimel J, Balser TC, Wallenstein M. 2007. Microbial stress-response physiology and its implications for ecosystem function. Ecology 88:1386-94.

Shaver GR, Chapin FS. 1980. Response to fertilization by various plant growth forms in an Alaskan tundra: nutrient accumulation and growth. Ecology 61:662-75.
Shaver GR, Chapin FS. 1991. Production-biomass relationships and element cycling in contrasting arctic vegetation types. Ecol Monogr 61:1-31.

Shaver G, Giblin A, Nadelhoffer K, Thieler K, Downs M, Laundre J, Rastetter E. 2006. Carbon turnover in Alaskan tundra soils: effects of organic matter quality, temperature, moisture and fertilizer. J Ecol 94:740-53.

Sistla SA, Asao S, Schimel JP. 2012. Detecting microbial N-limitation in tussock tundra soil: implications for Arctic soil organic carbon cycling. Soil Biol Biochem 55:78-84.

Sterner RW, Elser JJ. 2002. Ecological stoichiometry: the biology of elements from molecules to the biosphere. Princeton, NJ: Princeton University Press.

Sundqvist MK, Liu Z, Giesler R, Wardle DA. 2014. Plant and microbial responses to nitrogen and phosphorus addition across an elevational gradient in subarctic tundra. Ecology 95:1819-35.

Townsend-Small A, McClelland JW, Holmes RM, Peterson BJ. 2011. Seasonal and hydrologic drivers of dissolved organic matter and nutrients in the upper Kuparuk River, Alaskan Arctic. Biogeochemistry 103:109-24.

Vitousek PM, Reiners WA. 1975. Ecosystem succession and nutrient retention: a hypothesis. Bioscience 25:376-81.

Wallenstein MD, McMahon S, Schimel J. 2007. Bacterial and fungal community structure in Arctic tundra tussock and shrub soils. FEMS 59:428-35.

Weintraub MN. 2011. Biological phosphorus cycling in arctic and alpine soils. In: Bünemann E, Oberson A, Frossard E, Eds. Phosphorus in action: biological processes in soil phosphorus cycling. Soil Biology, Vol. 26. Berlin: Springer. p 295-316.

Weintraub MN, Schimel JP. 2005. The seasonal dynamics of amino acids and other nutrients in Alaskan Arctic tundra soils. Biogeochemistry 73:359-80.

Weishaar JL, Aiken GR, Bergamaschi BA, Fram MS, Fujii R, Mopper K. 2003. Evaluation of specific ultraviolet absorbance as an indicator of the chemical composition and reactivity of dissolved organic carbon. Environ Sci Technol 37:4702-8

Wickland KP, Neff JC, Aiken GR. 2007. Dissolved organic carbon in Alaskan boreal forest: sources, chemical characteristics, and biodegradability. Ecosystems 10:1323-40.

Wickland KP, Aiken GR, Butler K, Dornblaser MM, Spencer RGM, Streigl RG. 2012. Biodegradability of dissolved organic carbon in the Yukon River and its tributaries: seasonality and importance if inorganic nitrogen. Glob Biogeochem Cycles . doi:10.1029/2012GB004342.

Yavitt JB, Fahey TJ. 1986. Litter decay and leaching from the forest floor in Pinus contorta (Lodgepole pine). J Ecol 74:52545.

Zamin TJ, Grogan P. 2012. Birch shrub growth in the low Arctic: the relative importance of experimental warming, enhanced nutrient availability, snow depth and caribou exclusion. Environ Res Lett 7:034027. 